УДК 629.78 DОI: $10.30981 / 2587-7992-2018-97-4-28-43$

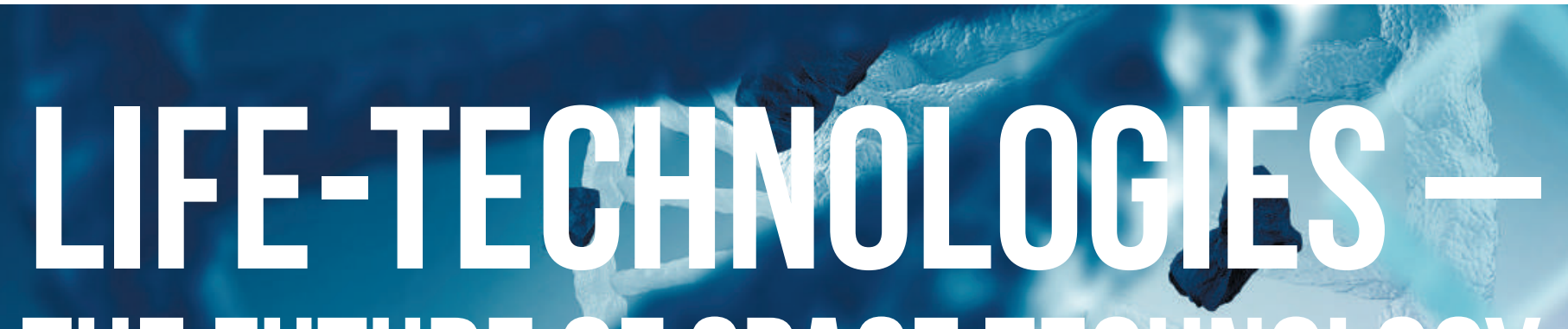

\title{
THE FUTURE OF SPACE
}
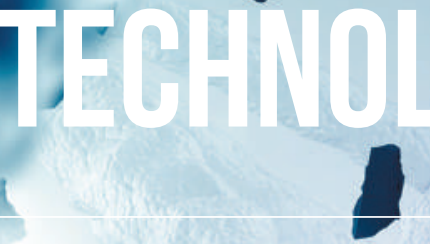

Valery Y. KLYUSHNIKOV,

Dr. Sci. (Tech), Senior Fellow, Chief Researcher, FSU "Central Research Institute of Machine Building ROSCOSMOS, Moscow, Russia, wkli59@yandex.ru
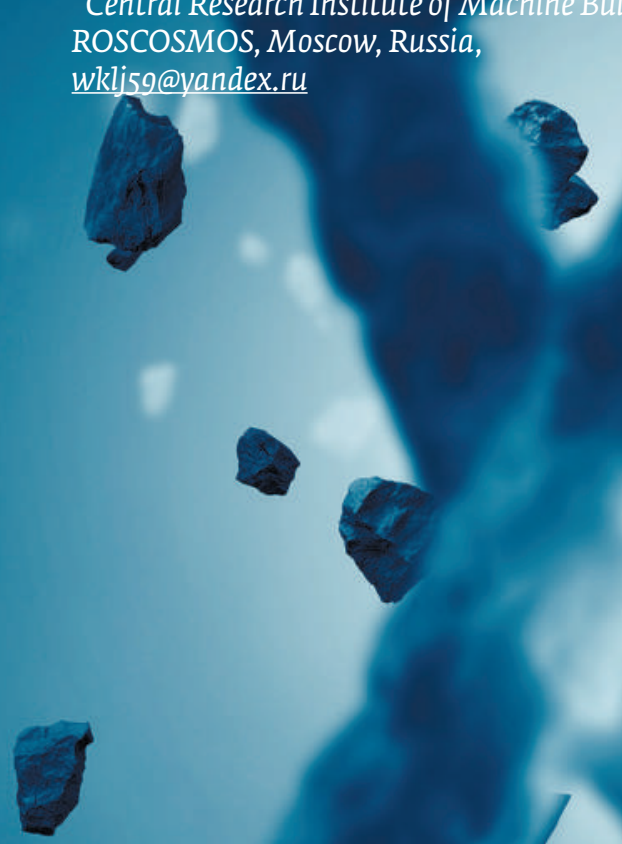

ABSTRACT I The author analyzes how bionic principles (life-technologies) can be realized in the context of the creation of the future space technology. These principles are based on the achievements of traditional life sciences as well as of emerging sciences, such as non-organic biochemistry and synthetic biology.

Keywords: bionics, space technology, super-adaptation, the trends of engineering systems development, regenerati uration
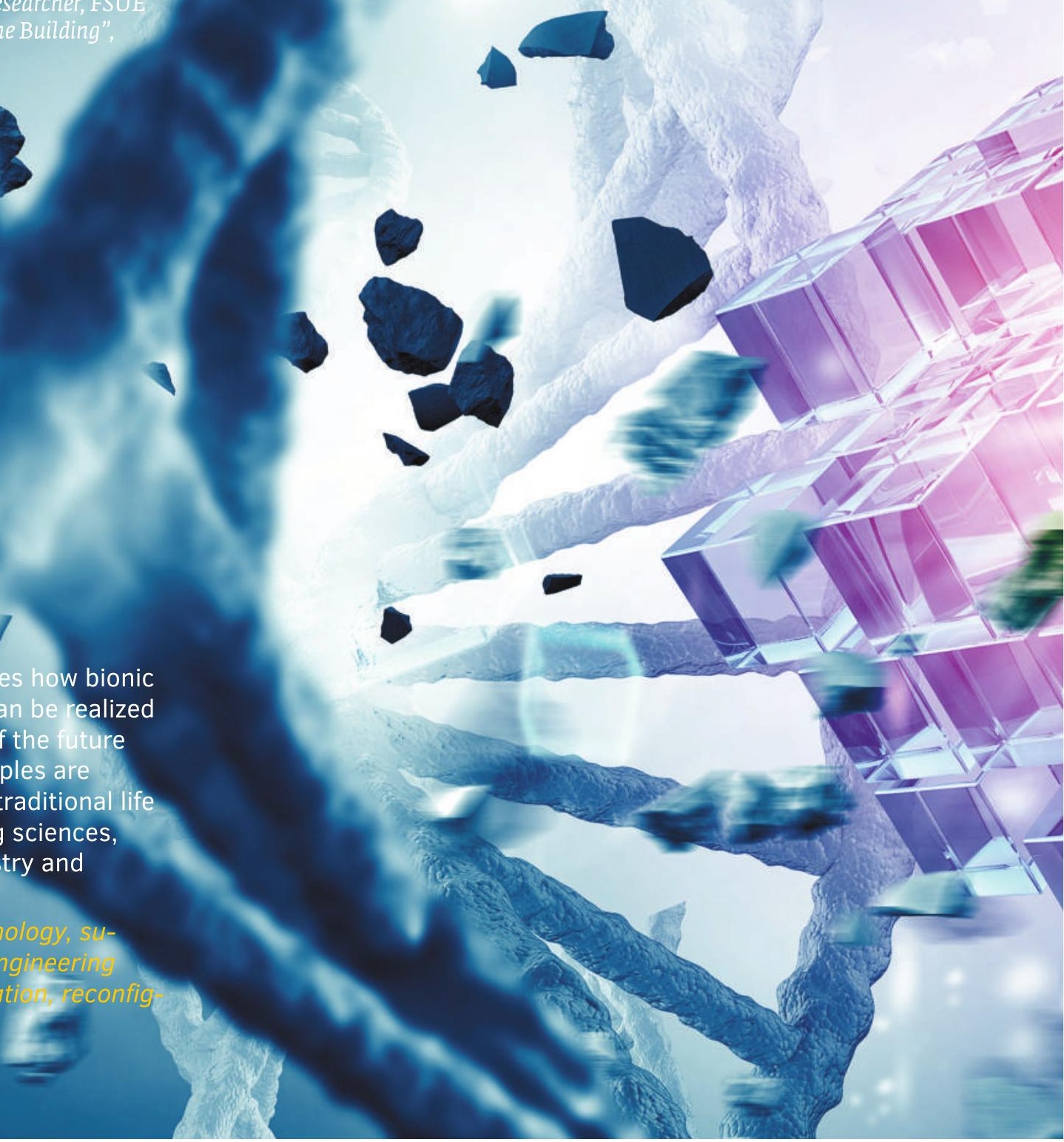

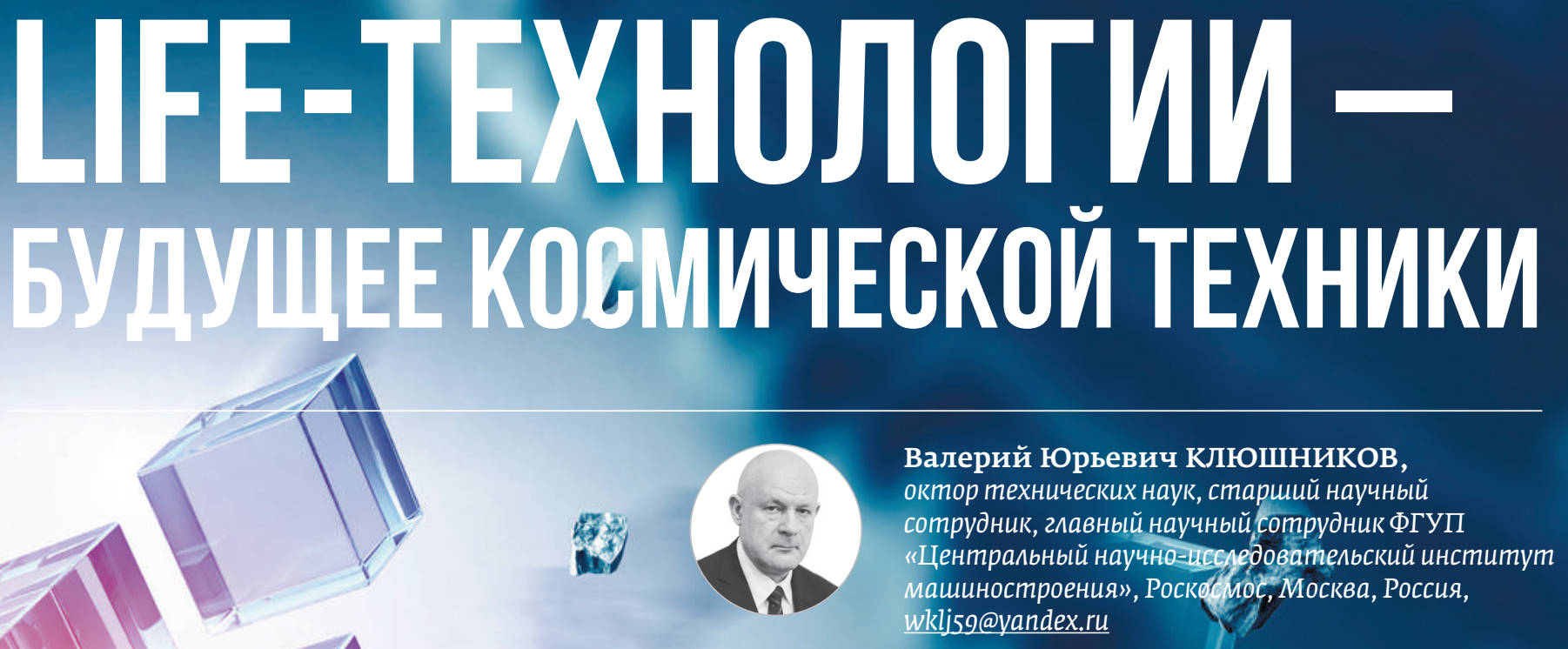

Валерий Юрьевич КЛЮшНиков,

сотрудник, главный научный сотрудник ФГУП

"Центральный научно-нсследовательский институт wkli5g@yandex.ru
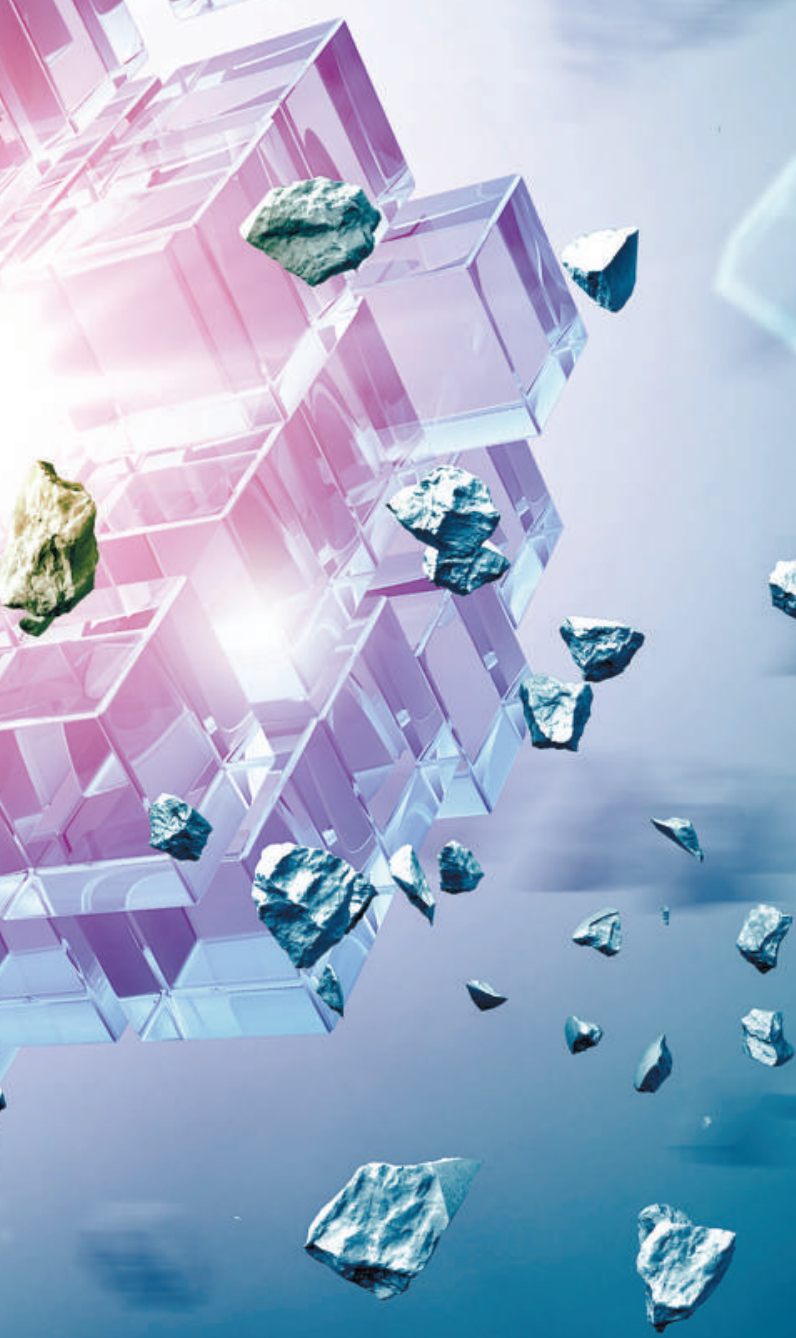

Ключевые слова: бионика, космическая

мехника, суперадаптация, закономерности развития технических систем,

регенерация, реконфигурация 


\section{ВВЕДЕНИЕ}

На всем протяжении существования цивилизации человек часто пытался заимствовать у живой природы идеи своего технологического развития. В начале 1960-х годов появилась новая наука - бионика, являющаяся пограничной между биологией и техникой и решающая инженерные задачи на основе моделирования структуры и жизнедеятельности организмов. В последнее время входят в обиход термины «природоподобные технологии» (синоним - life-технологии), «зеленые технологии» и даже «зеленая экономика».

Человечество находится на пороге перехода к новому, шестому технологическому укладу, ключевыми факторами которого станут биотехнологии, нанотехнологии, когнитивные технологии, робототехника, материалы с заранее заданными свойствами и т. д.

Однако на первый план все же выходят биотехнологии, поскольку именно они, по аналогии, например, с кибернетикой в 50-6о-е годы прошлого века, вполне могут стать интегральной областью, объединяющей в себе различные аспекты других отраслей науки и технологии, включая и нанотехнологии, и робототехнику, и когнитивные технологии, и многие другие направления. Наконец, следует учесть исключительные коммерческие перспективы внедрения новых биотехнологий, обусловленные, прежде всего, потребностями медицины.

Таким образом, технологический уклад определяет некий «коридор», в котором развитие технологий, в частности биотехнологий, пойдет наиболее быстрыми темпами. В этой связи можно прогнозировать второе дыхание бионики как нау- ки, в том числе и в области космической техники. Анализ некоторых особенностей живых организмов на новом уровне технологического развития мог бы дать новый импульс и подсказать новые направления развития космической техники, а также технологические предпосылки реализации таких направлений.

Космическая техника, как и ряд некоторых других типов технических систем, достигла уровня сложности, сопоставимого по некоторым показателям со сложностью биологических систем. Можно провести соответствие между структурными уровнями организации и свойствами биологической и технической систем. И в том, и в другом случае можно выделить 5 уровней структурной организации и 10 основных свойств (рис. 1).

Разумеется, содержательная сложность перечисленных свойств биосистем пока что не идет ни в какое сравнение со сложностью свойств технических систем.

Если попытаться спрогнозировать требования $\mathrm{K}$ космическим кораблям середины-конца XXI века, предназначенным для исследования и освоения дальних планет Солнечной системы, то можно прийти к выводу, что, прежде всего, необходимо радикально изменить подход к обеспечению надежности и автономности космической техники. Помимо этого, желательно перемещаться в пространстве с как можно большей скоростью при минимальных затратах энергии. И наконец, необходимо обеспечить условия для безопасного и достаточно комфортного пребывания экипажа в космическом корабле в течение длительного времени.

\section{1. ВОЗМОЖНЫЕ НАПРАВЛЕНИЯ ИСПОЛЬЗОВАНИЯ LІFЕ-ТЕХНОЛОГИЙ В КОСМИЧЕСКОЙ ТЕХНИКЕ}

\section{1. НАДЕЖННОСТЬ И АВТОНОМНОСТЬ КОСМИЧЕСКОЙ ТЕХНИКИ}

Подход к обеспечению надежности и автономности космической техники может быть радикально изменен на основе воспроизводства свойства суперадаптации, присущего биологическим системам (в определенной области характеристик внешней среды).

Суперадаптация в биологических системах обеспечивается за счет практически всех основных свойств живых объектов и заключается:
- в возможности выполнять целевую функцию в условиях меняющихся внешних условий и воздействий, в том числе экстремальных;

- в способности элементов (составных частей) системы взаимно адаптироваться к изменению состояния друг друга, вызванному воздействием внешних или внутренних факторов, и автоматически устранять повреждения (регенерация).

В соответствии с этой классификацией различают внешний и внутренний контуры суперадаптации.
В максимальной степени обеспечить возможность выполнения целевой функции в условиях меняющихся внешних воздействий, в том числе экстремальных, способен биологический объект, обладающий интеллектом или развитыми инстинктами (по сути, инстинкты - зачатки интеллекта).

Что касается регенерации и репарации, то следует обратить внимание на то, что система физиологической регенерации в биологических объектах является механизмом обеспечения «штатного» функционирования 


\section{РИС. І. СООТВЕТСТВИЕ МЕЖДУ СТРУКТУРНЫМИ УРОВНЯМИ ОРГАНИЗАЦИИ И СВОЙСТВАМИ БИОЛОГИЧЕСКОЙ И ТЕХНИЧЕСКОЙ СИСТЕМ}

\begin{tabular}{l|l|}
\hline Структурные уровни живой материи & Структурные уровни технической системы \\
\hline Молекулярно-генетический & Микро-, наноструктура конструкционных материалов \\
\hline Клеточный & Электронная компонентная база, электромеханические компоненты \\
\hline Онтогенетический (организменный) & Приборы, системы и агрегаты \\
\hline Популяционно-видовой & Изделия (ракета-носитель, космический аппарат и т. д.) \\
\hline Биосферный (биогеноценотический) & Ракетно-космическая техника
\end{tabular}

СООТВЕТСТВИЕ МЕЖДУ СВОЙСТВАМИ ИЗДЕЛИЯ РАКЕТНО-КОСМИЧЕСКОЙ ТЕХНИКИ И СВОЙСТВАМИ БИОЛОГИЧЕСКИХ СИСТЕМ

\begin{tabular}{|c|c|}
\hline Свойства живого & Краткая характеристика аналогичного свойства в космической системе \\
\hline $\begin{array}{l}\text { 1. Единство структурной } \\
\text { организации }\end{array}$ & $\begin{array}{l}\text { Электронная компонентная база, электромеханические компоненты, прибо- } \\
\text { ры, агрегаты, системы - унифицированные структурные единицы изделия } \\
\text { космической техники }\end{array}$ \\
\hline 2. Дискретность и целостность & $\begin{array}{l}\text { Изделие КТ состоит из взаимодействующих элементов, систем и агрегатов, } \\
\text { образующих единое целое }\end{array}$ \\
\hline 3. Метаболизм & $\begin{array}{l}\text { Изделие КТ состоит из взаимосвязанных процессов потребления, преобразо- } \\
\text { вания и диссипации различных видов энергии (в настоящее время - химиче- } \\
\text { ской, электрической, механической и ядерной) }\end{array}$ \\
\hline 4. Саморегуляция & $\begin{array}{l}\text { Сохранение относительного постоянства внутренней среды изделий КТ - тем- } \\
\text { пературы и газового состава }\end{array}$ \\
\hline 5. Открытость & $\begin{array}{l}\text { Поддержание постоянного обмена веществом и энергией между внутренней } \\
\text { и внешней средой изделия КТ, техническое обслуживание КА в полете }\end{array}$ \\
\hline 6. Размножение & $\begin{array}{l}\text { Обеспечивает непрерывность существования и преемственность модификаций и } \\
\text { новых изделий. В будущем возможна реализация репликации автоматических КА }\end{array}$ \\
\hline $\begin{array}{l}\text { 7. Наследственность } \\
\text { и изменчивость }\end{array}$ & $\begin{array}{l}\text { Поддержание относительного постоянства элементарной базы, переход на } \\
\text { новую технологическую базу при изменении технологического уклада }\end{array}$ \\
\hline 8. Рост и развитие & $\begin{array}{l}\text { В широком смысле - появление новых изделий. В узком смысле - изменение } \\
\text { конструкции изделия в пелете (например, за счет стыковки новых систем) }\end{array}$ \\
\hline 9. Раздражимость и движение & Реагирование на команды бортового и наземного комплексов управления \\
\hline 10. Ритмичность & $\begin{array}{l}\text { Многолетние, годичные, сезонные, месячные, суточные ритмы - как приспо- } \\
\text { собление к меняющимся условиям среды (разворот солнечных батарей за } \\
\text { Солнцем, изменение угловой ориентации изделия КТ для съемки, включение } \\
\text { целевой аппаратуры, коррекция орбиты и т. д.) }\end{array}$ \\
\hline
\end{tabular}

РИС. 2. ВНЕШНИЙ КОНТУР АДАПТАЦИИ КА К ИЗМЕНЕНИЮ УСЛОВИЙ ФУНКЦИОНИРОВАНИЯ, ВКЛЮЧАЯ ОТКАЗЫ БОРТОВЫХ СИСТЕМ

ИНТЕЛЛЕКТУАЛЬНАЯ ИНФОРМАЦИОННО-УПРАВЛЯЮЩАЯ СИСТЕМА

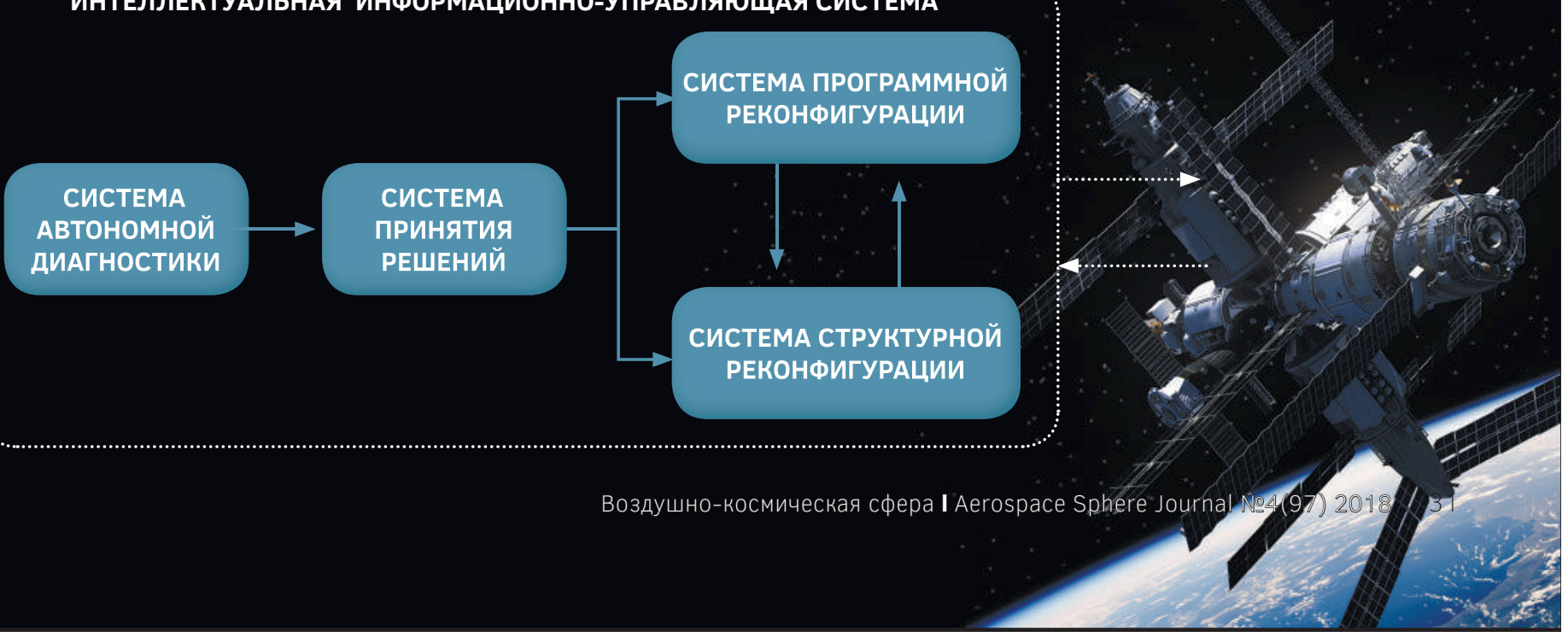


биообъекта. Этот механизм направлен на своевременную «замену» отдельных износившихся (но не отказавших!) элементов (смена клеток крови, эпидермиса), обновление клеточных органелл и т. д. В то время как репаративную регенерацию можно было бы назвать механизмом ликвидации так называемых аварийных ситуаций (например, структурных повреждений после действия патогенных факторов и даже внешних физических воздействий).

В настоящее время в АО «РКЦ „Прогресс"», вне зависимости от бионических принципов, сформулированы общие подходы $\mathrm{k}$ реализации частных свойств жизнеспособности космических аппаратов (KA) [1]. В данном случае легко видеть, что, например, неуязвимость бортовых систем и отказоустойчивость - свойство, аналогичное гомеостазу живых объектов. Адаптивность бортовых систем (БС) к отказам компонентов близка к физиологической регенерации в биообъектах, а восстанавливаемость состояний работоспособности КА при отказах БС - к репаративной регенерации.

Тем не менее, реализация описанных в [2] принципов - еще не суперадаптация. Не выделены явно внешний и внутренний контуры адаптации (хотя нужно признать, что это сложно сделать корректно). Устойчивость к отказам и адаптация к нештатным ситуациям реализуются в основном за счет различных видов избыточности. Пока еще низка автономность КА и т. д.

В основу построения внешнего контура адаптации может быть положена способность системы к структурной и программной реконфигурации и автономному принятию решений на основе результатов автономной диагностики с использованием средств искусственного интеллекта (рис. 2).

В настоящее время используют два способа структурной реконфигурации бортовой аппаратуры KA [2]:

- многоуровневая реконфигурация электронной аппаратуры, построенной по технологии программируемых логических интегральных схем (ПлиС); ПлиС, благодаря своей гибкой структуре, позволяют осуществлять оперативную peконфигурацию (перепрошивку) внутренней архитектуры в процессе функционирования;

- динамическая перестройка поля однородной вычислительной системы (ОВС) в процессе решения задач управления КА; ОВС представляет собой регулярную структуру - геометрически правильную решетку, в каждом узле которой находится ячейка, выполняющая простейшие вычислительные и коммутационные функции. В ОВС реализована полная децентрализация управления, преобразования и хранения информации.

Сама идея реконфигурируемой системы подразумевает в некоторой степени автономность каждой вычислительной ячейки (ВЯ), в которой должна храниться информация обо всех других ВЯ регенеративной системы, для того, чтобы в процессе реконфигурации не образовались связи с ранее вышедшими из строя элементами.

Непосредственно в орбитальном полете может быть осуществлена также реконфигурация бортового программного обеспечения (рис.3).

Дальнейшим шагом в развитии подходов к обеспечению свойств суперадаптации космической техники может стать внедрение реконфигурируемых эволюционных аппаратных систем [3] .

В основе эволюционных систем лежат эволюционные алгоритмы, реализующие методологию поиска решений для получения оптимальной архитектуры бортовых систем. В качестве аппаратной платформы при создании эволюционных систем могут выступать реконфигурируемые устройства на ПлИС или поля ОВС.

Внутренний контур адаптации должен иметь возможности по восстановлению различных отказавших функциональных систем (рис. 4). Так, например, уже сейчас проводятся экспериментальные исследования возможностей так называемых интеллектуальных материалов контролировать внешние воздействия на элементы конструкции технических систем и изменять свои физические параметры под воздействием внешних управляющих сигналов. Результаты таких исследований могут быть использованы для создания систем регенерации элементов конструкции в космической технике. Ведутся работы также в области систем восстановления отказавших интегральных схем и поврежденных электронных плат (рис.4) [4] .

Радикально решить проблему регенерации отказавших и даже разрушенных элементов конструкции изделий космической техники в полете позволят аддитивные технологии. Сегодня такие технологии лишь в начале пути. Однако уже сейчас просматриваются обнадеживающие технические решения и концепты. Так, например, HACA развивает аддитивные технологии в направлении их „гибридизации“ с обычной сваркой, технологии переработки мусора в космосе в сырье для 3D-принтеров и т. д. $[5,6]$. 
РИС. 3. СИСТЕМА РЕКОНФИГУРАЦИИ БОРТОВОГО ПРОГРАММНОГО ОБЕСПЕЧЕНИЯ

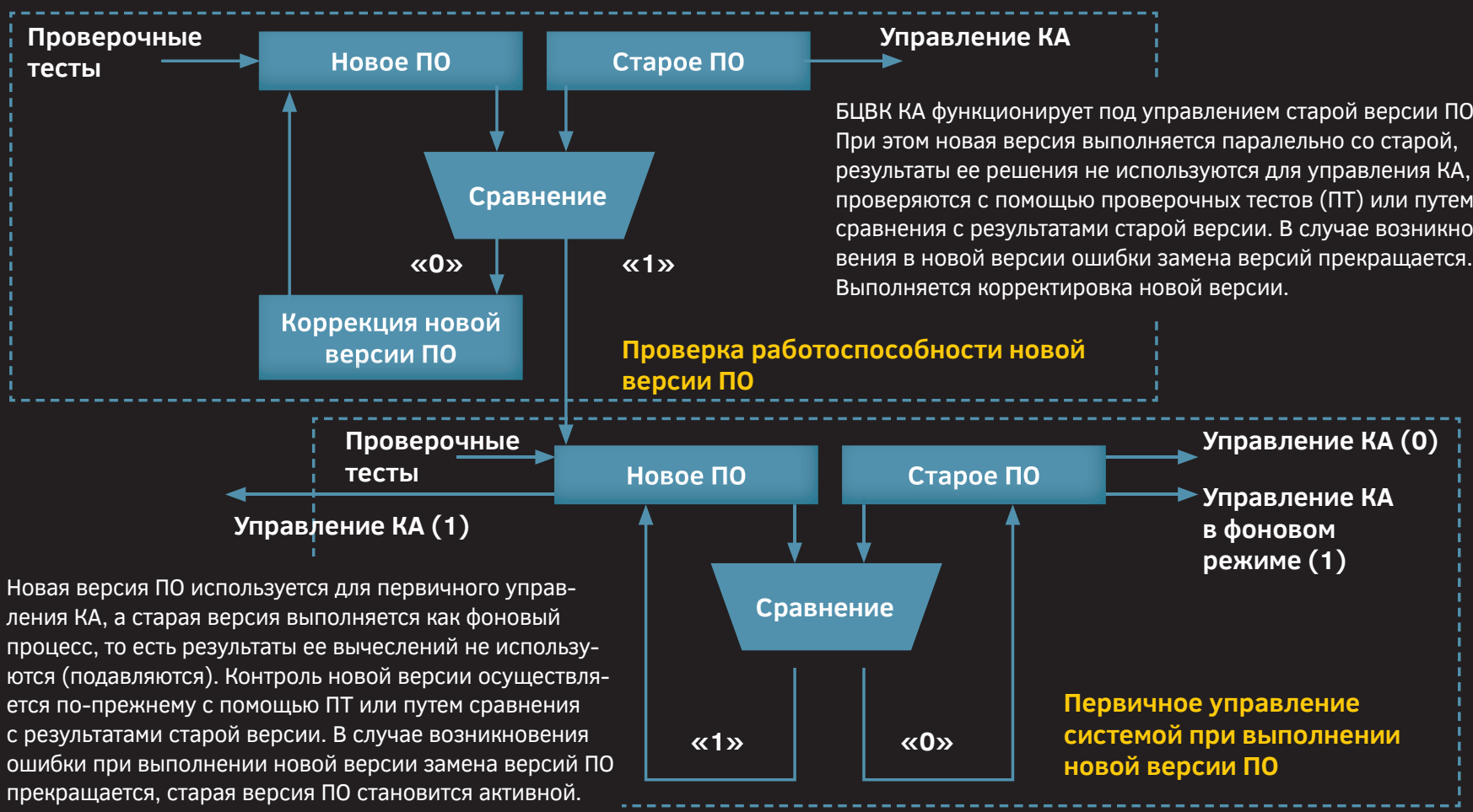

РИС. 4. ВНУТРЕННИЙ КОНТУР АДАПТАЦИИ: РЕГЕНЕРАЦИЯ ЭЛЕКТРОЦЕПЕЙ И КОНСТРУКЦИОННЫХ МАТЕРИАЛОВ

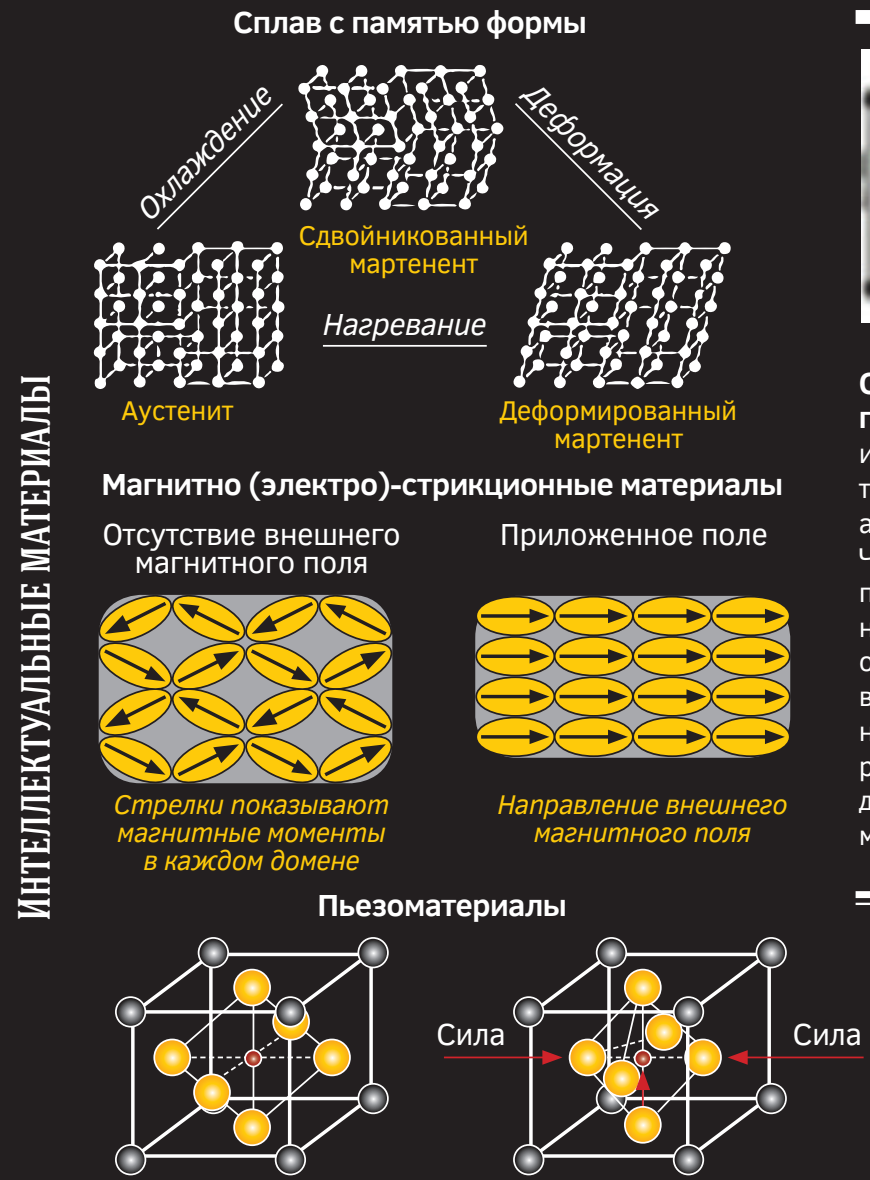

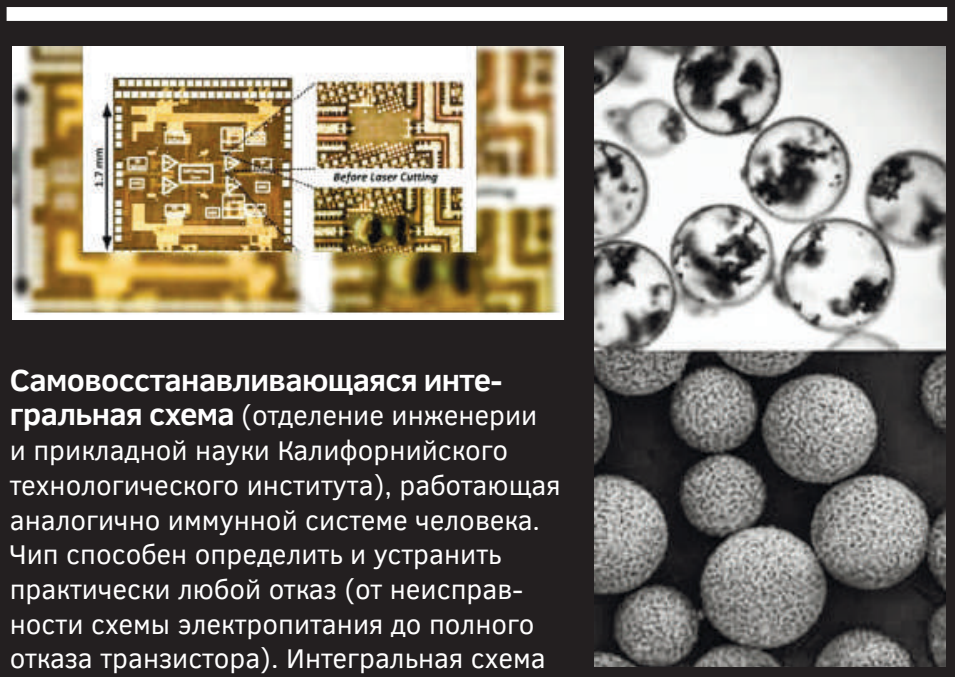

в каждой ситуации отказа строит уникальный алгоритм восстановления, ориентируясь на текущую совокупность сигналов датчиков температуры, потребляемой мощности и силы тока
Свинец
Кислород
○ Титан или цирконий

Самовосстанавливающаяся электронная плата (Университет Иллинойса). Самовосстанавливание при нарушении целостности платы в результате механического воздействия происходит за счет разрыва капсул, наполненных нанотрубками с проводящими свойствами. 
TAK КАК В НАНОЯЧЕИКАХ

РЕАЛИЗОВАН АНАЛОГ МЕХАНИЗМА

СОХРАНЕНИЯ ДОЛГОВЕЧНОСТИ

ЭНЕРГЕТИЧЕСКИХ СИСТЕМ РАСТЕНИЙ,

ОНИ МОГУТ СТАТЬ ОСНОВОЙ

ДОЛГОВЕЧНЫХ БАТАРЕЙ.

1.2. СНАБЖЕНИЕ ЭЛЕКТРОЭНЕРГИЕЙ B KOCMOCE

В длительных космических полетах, в частности, на большом расстоянии от Солнца, будут необходимы надежные, эффективные и компактные системы электроснабжения.

В основу построения таких систем могут быть положены принципы фотосинтеза зеленых растений. Группа исследователей из четырех университетов и институтов США использовала натуральные фотосинтетические реакционные центры для построения фотоэлектрохимических комплексов нанометрового масштаба [7].

B наноячейках реализован аналог механизма сохранения долговечности энергетических систем растений: циклический процесс „... самосборка $\rightarrow$ разрушение $\rightarrow$ самосборка...“ фотоэлектрических панелей нанометрового поперечника из фосфолипидов (компонентов клеточных мембран), углеродных нанотрубок и поверхностно активных веществ (ПАВ). При подключении контактов $\mathrm{k}$ наноячейкам они отдают часть электронов в сеть. В перспективе эти наноячейки могут стать основой долговечных батарей .

Возможно, перспективным направлением создания бионических систем энергоснабжения в космосе может явиться исследование феномена биотрансмутации - низкоэнергетических ядерных реакций, происходя- щих в живых растениях (гипотеза, [8]). Можно предположкить, что понимание механизмов биотрансмутации позволит биологическим путем получать, например, актиний-227 (сегодня стоимость актиния-227 составляет миллионы долларов за грамм). Преимущества этого изотопа перед другими - в экологической чистоте и высоком удельном энерговыделении $(14,5$ Вт/г). Актиний-227 был бы незаменим для создания бортовых термоэлектрических генераторов.

\section{3. ИСКУССТВЕННЫЙ ИНТЕЛЛЕКТ НА БОРТУ КОСМИЧЕСКИХ АППАРАТОВ}

Говоря о суперадаптации в космической технике, нельзя не упомянуть исследования в области нейрофизиологии, в частности, феноменов интеллекта и сознания. Именно интеллект лежит в основе высокой автономности КА и адаптации к условиям меняющейся операционной обстановки, а также к внешним воздействиям, в том числе экстремальным.

В последние годы получило известность теоретическое и экспериментальное обоснование механизмов сознания под руководством члена-корреспондента РАН Константина Владимировича Анохина (Курчатовский НБИКС-центр). К.В. Анохиным предложено исследовать не все без исключения связи между нейронами, а только такие их совокупности, активация которых соответствует единицам когнитивного (познавательного) опыта [9]. В рамках этой новой концепции постулируется, что феномен мышления и сознания порождается синхронной работой нейронных ансамблей (рис. 6).

Результаты исследований К.В. Анохина могут быть использованы при создании нового поколения распределенных бортовых вычислительных (интеллектуальных) систем, способных как решать традиционные задачи управления движением и работой бортовых систем космических аппаратов, так и служить экспертной и информационно-справочной системой поддержки экипажа пилотируемого корабля.

Перспективным направлением исследований проблемы сознания являются также работы в области роевого интеллекта. Роевый интеллект представляет собой многоагентную систему с самоорганизующимся поведением, которое интегрально является квазиразумным. В живой природе такого рода интеллектом обладают муравейники, рои пчел, стаи рыб. Именно принципы роевого интеллекта, по-видимому, будут лежать в основе автономной системы управления кластером (роем) КА, позволяющей решать задачи оптимального распределения целевой функции кластера между отдельными КА и согласованного управления ее реализацией.

\section{4. ИНЕРЦИАЛЬНЫЕ ИЗМЕРИТЕЛЬНЫЕ ДАТЧИКИ}

У всех представителей животного мира, ведущих подвижный образ жизни, выявлены инерциальные измерители [10]. Все они имеют принципиально одинаковое устройство (рис. 7), хотя различия в условиях существования, скоростях движения и способах перемещения привели к возникновению множества разновидностей миниатюрных, высокочувствительных инерциальных сенсоров.

Наиболее высокой информативности и степени совершенства инерциальные органы достигли у теплокровных (птиц и млекопитающих), в организмах которых поддерживается постоянная температура.

Инерциальные биодатчики ускорений позвоночных сосредоточены в едином комплексе - вестибулярном аппарате, который включает в себя два комплекта 


\section{РИС. 5. ВНУТРЕННИЙ КОНТУР АДАПТАЦИИ - РЕГЕНЕРАЦИИ СИСТЕМ ЭНЕРГОСНАБЖЕНИЯ}

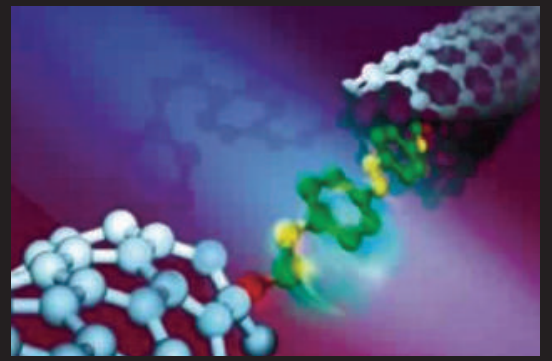

Солнечные батареи, работающие по принципу фотосинтеза у растений: имитируется механизм молекулы растения, в котором светочувствительные молекулы постоянно сами себя воспроизводят (Группа ученых под руководством Майкла Страно (Michael Strano) из Массачусетского технологического института (МIT). США).

\section{Работа фотосинтеза}

УГЛЕКИСЛЬЙ ГАЗ

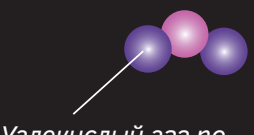

углекислый газ поставляет углерод, чтобы построuть углеводы

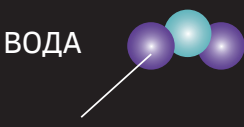

Вода легко абсорбируется водными растениями
Пигменты, такие как хлорофилл, используются как ловушка для энергии солнечного света, с иелью дальнейшего фотосинтеза

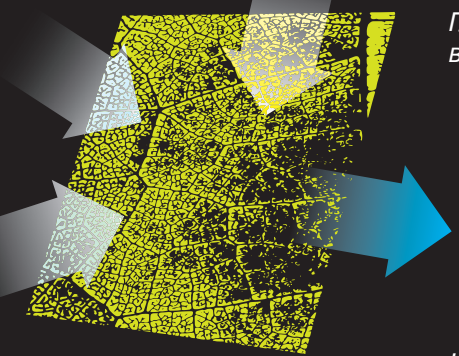

Углерод, кислород, водород, углекислый газ и вода «перестраиваются» внутри клеток растений
ГЛЮКОЗА

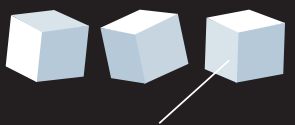

Глюкоза, произведенная в процессе фотосинтеза

кИслОРОД

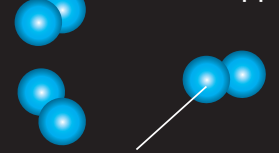

Кислород выделяется в качестве побочного продукта

\section{ИДЕАЛИЗИРОВАННАЯ СХЕМА "ЖИВОЙ» СОЛНЕЧНОЙ ЯЧЕЙКИ}

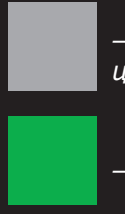

- реакционные чентры

- липидные диски
- углеродные нанотрубки, собирающие ток от фотосинтетических белков

- общий электрод

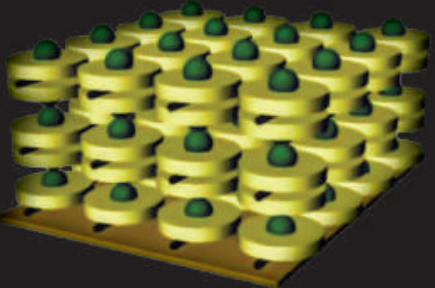

\section{РИС. 6. СЕТЕВАЯ ОРГАНИЗАЦИЯ РАЗУМА}

\begin{tabular}{l|l|l|} 
No & УТВЕРЖДЕНИЯ \\
\hline 1 & Разум гранулярен \\
\hline 2 & Разум увязан \\
\hline 3 & Разум целостен \\
\hline
\end{tabular}

ПРИНЦИПы
Разум обладает зернистой структурой и состоит из когов - элементарных
единиц опыта, кодирующих соотношение целого организма с теми или иными
аспектами мира.
Элементы разума - коги - имеют между собой устойчивые связи - коммы, по кото-
рым осуществляются их коммуникации.
Коги и коммы образуют сеть - когнитом. Когнитом является субстратом субъектив-
ного опыта организма, опосредующего его отношения со средой.

\section{поняТия}

ко2 КОМм KOEHUMOM когнитом

Феномен мышления и сознания порождается синхронной работой огромных, но все же небольших по сравнению с полным объемом, распределенных сетей нейронов - нейронных ансамблей.

Проект «Прозрачный мозг»

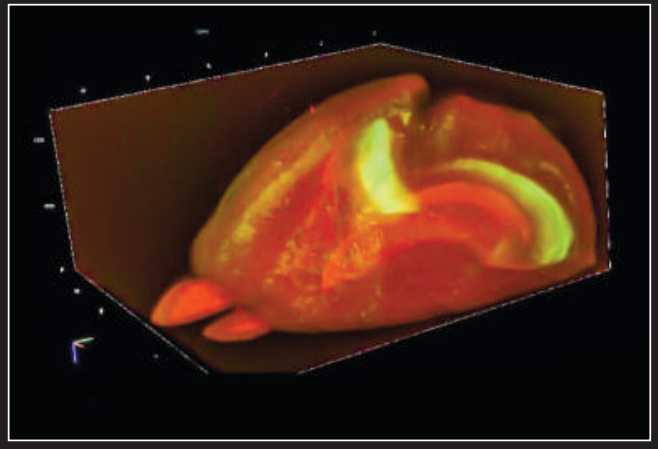

Визуализация детальной нейронной сети целого мозга мыши с клеточным разрешением

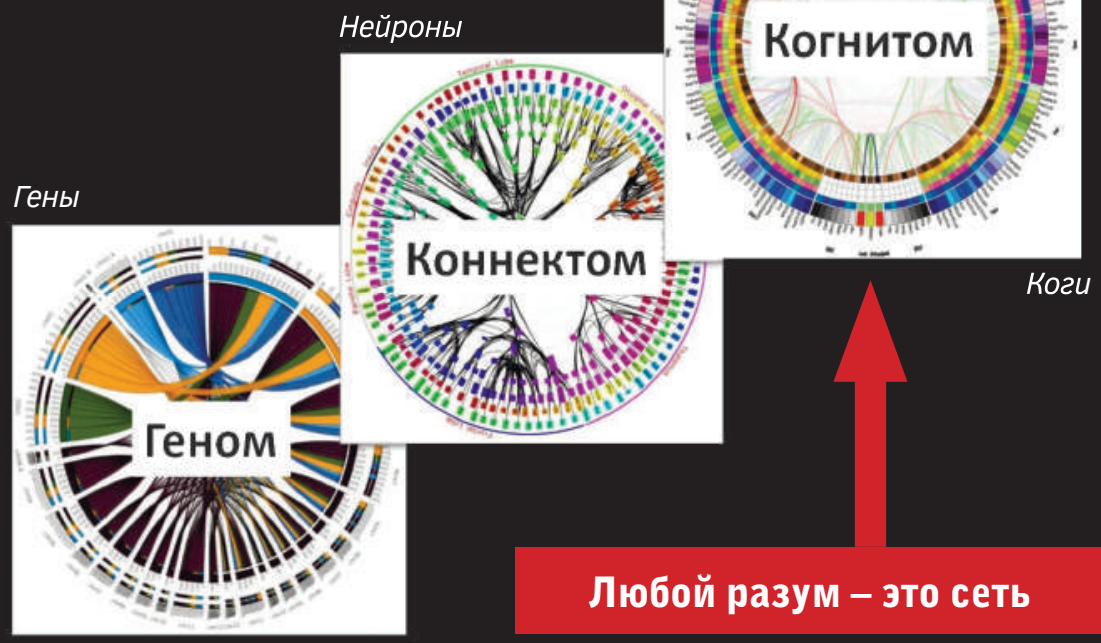

Воздушно-космическая сфера I Aerospace Sphere Journal №4(97) 201835 
инерциальных биодатчиков (левый и правый), разнесенных на некоторую базу и повернутых зеркально-симметрично относительно центра головы.

Вестибулярные органы чувств имеют весьма высокие характеристики точности, надежности и информативности, в то же время их масса, габаритные размеры и энергопотребление на несколько порядков меньше, чем у технических аналогов.

1.5. ОБЕСПЕЧЕНИЕ ЭРГОНОМИЧНОСТИ ПИЛОТИРУЕМЫХ КОСМИЧЕСКИХ КОРАБЛЕЙ ИБЕЗОПАСНОСТИ ЭКИПАЖА

Следует отметить, что космос является для человека крайне враждебной средой, несущей, помимо тех опасностей, о которых мы имеем представление, и неизвестные угрозы. Сверхдальние пилотируемые полеты могут потребовать решения проблем производства пищи, свободного пространства на корабле для эффективной работы и полноценного отдыха космонавтов и других задач жизнеобеспечения.

Безопасность экипажа и высокая эргономичность пилотируемых космических кораблей будущего может быть достигнута путем новых конструкторских решений, в том числе основанных на бионических принципах. Прежде всего, следует иметь в виду замкнутые биологические системы жизнеобеспечения, а также и гибернацию или анабиоз (рис. 7).

Замкнутая биологическая
система жизнеобеспечения
(БСОЖ) представляет собой ана-
лог природной экологической
системы. Без БСожневозможны
длительные автономные поле-
ты в дальний космос. Существу-
ющие сож, например на стан-
циях серии «Салют» и «Мир»,
на Международной космиче-
ской станции, нельзя назвать

замкнутыми и биологическими, поскольку периодически при помощи грузовых космических кораблей осуществляется доставка на станцию не только ракетного топлива, но и продуктов питания, медицинских препаратов и других расходных материалов. В лучшем случае существующие СОЖ могут быть замкнутыми по отдельным циклам, например, по воде.

Первая масштабная попытка натурного моделирования процессов, происходящих в естественных экосистемах Земли, была неудачной. В 1984-1991 годах в американской пустыне Аризона проводился масштабный эксперимент по созданию искусственной замкнутой среды обитания, получивший название "Биосфера-2» (подразумевалось, что «Биосферой-1» является наша планета Земля) [11] .

Под закрытый купол площадью

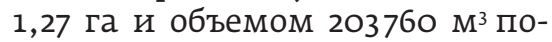
местили более 3000 видов растений и животных, смоделировали семь биомов (лес, саванна, пустыня, болото, океан с коралловым рифом, сельскохозяйственные угодья). Планировалось, что восемь человек проживут под куполом два года.

Однако через 15 месяцев после закрытия изолирующей оболочки эксперимент были вынуждены прекратить, поскольку:

- уровень кислорода упал до критического;

- вымерло 18 из 25 помещенных под купол видов позвоночных;

- вымерло большинство насекомых;

- возникли серьезные проблемы с загрязнением воды и воздуха и регулированием температуры.

Очевидно, реализация искусственной экосистемы в меньших объемах вызовет еще больше трудностей.

Из всех искусственных БСОЖ, созданных в мире до настоящего времени, наибольших успехов удалось добиться в экспери- менте БИОС-3. В автономном режиме обеспечивалась жизнь трех человек в течение шести месяцев за счет замыкания цикла по воде и газу почти на 100\%, пище - более чем на 50 \% [12].

Самый серьезный недостаток замкнутых БСОЖ, который необходимо будет преодолеть в будущем,- их низкий энергетический КПд и, как следствие, значительные размеры и масса.

Для реализации амбициозных планов по освоению дальнего космоса, по пилотируемым полетам к астроидам и другим планетам предстоит решить множество проблем, в числе которых чрезвычайно большая потребная масса экспедиционного корабля и, соответственно, высокая стоимость подобных космических экспедиций. Одним из направлений решения такой проблемы может стать погружение экипажа в глубокий сон в идеале в анабиоз или гибернацию (рис. 8).

Гибернация - это замедление жизнедеятельности человека путем блокировки нейроэндокринных механизмов терморегуляции. Анабиоз по сравнению с гибернацией сопровождается более глубоким подавлением жизнедеятельности. Живые организмы, впадающие в анабио3, могут терять от половины до трех четвертей заключенной в тканях воды. Для человека это критично, и проблема его погружения в анабиоз до сих пор не решена, в отличие от гибернации. Состояние гибернации же достигается понижением температуры в интервале от $31,6^{\circ} \mathrm{C}$ до $33,8^{\circ} \mathrm{C}$.

Расчеты показывают, что введение экипажа марсианской экспедиции в состояние глубокого сна позволит сократить общую массу корабля с 400 до 220 тонн за счет того, что можно в пять раз уменьшить необходимое пространство для экипажа, а также в три раза - количество грузов, необходимых для обеспечения жизнедеятельности [13]. 
РИС. 7. ОБОБЩЕННАЯ СХЕМА ИНЕРЦИАЛЬНОГО БИОДАТЧИКА БЕСПОЗВОНОЧНЫХ ЖИВОТНЫХ:

1 - пузырек; 2 - студенистая жидкость; 3 - тяжелые частицы (у одноклеточных - несколько кристаллических конкреций, у моллюсков - известковые шарики, у ракообразных - песчинка, заимствованная из окружающей среды); 4 - упругие ворсинки; 5 - нервные элементы

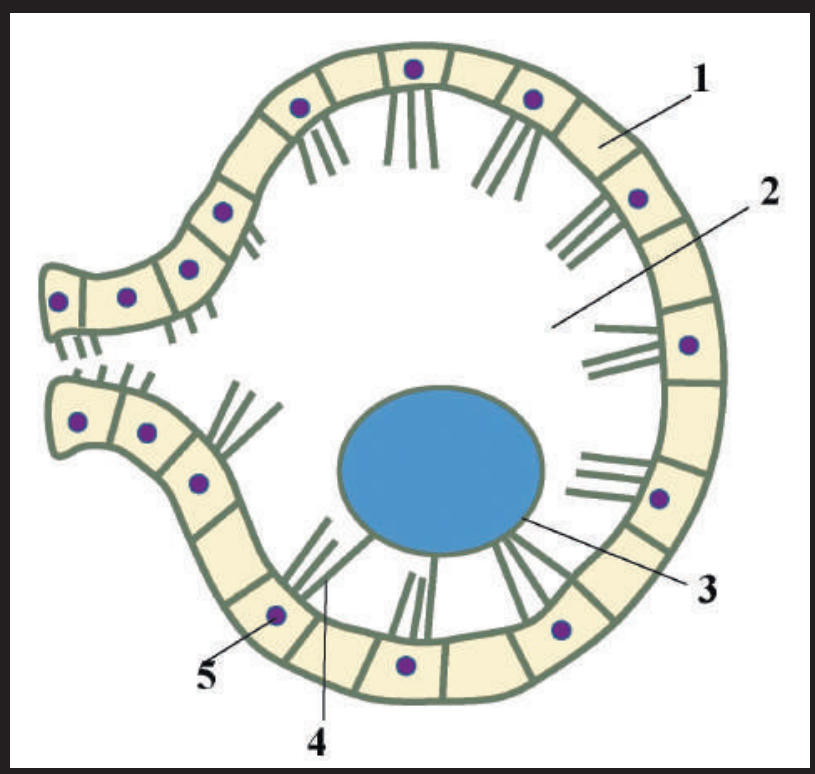

ВВЕДЕНИЕ ЭКИПАЖА МАРСИАНСКОЙ

ЭКСПЕДИЦИИ В СОСТОЯНИЕ

ГЛУБОКОГОСНА ПОЗВОЛИТ

СОКРАТИТЬ ОБЩУЮ МАССУ

КОРАБЛЯС 400 ДО 220 ТОННИ,

СЛЕДОВАТЕЛЬНО, В ПЯТЬ РАЗ

УМЕНЫШИТЬ НЕОБХОДИМОЕ

ПРОСТРАНСТВО ДЛЯ ЭКИПАЖА,

А ТАКЖКЕ В ТРИ РАЗА - КОЛИЧЕСТВО

ГРУЗОВ ДЛЯ ОБЕСПЕЧЕНИЯ

ЖИЗНЕДЕЯТЕЛЬНОСТИ.
РИС. 8. ГИБЕРНАЦИЯ И АНАБИОЗ

Гибернация - искусственно созданное состояние замедленной жизнедеятельности организма у теплокровных животных, в том числе и человека, напоминающее состояние животного в период зимней спячки, которое достигается при помощи нейроплегических средств, блокирующих нейро-эндокринные механизмы терморегуляции.

\section{Система жизнеобеспечения}

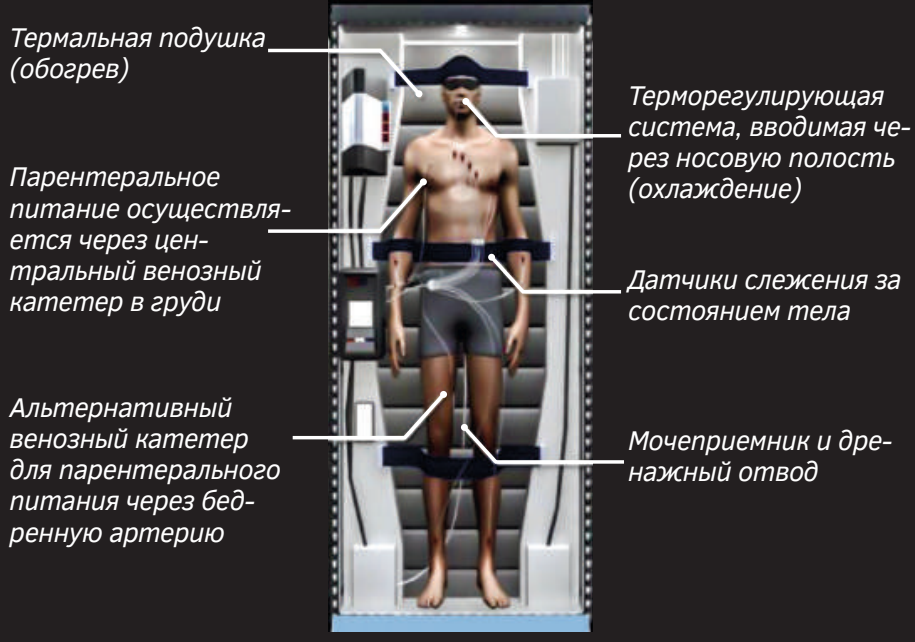

Космическая гибернация

Анабиоз - временное замедление или прекращение жизненных процессов в организме под воздействием внешних или внутренних факторов. При этом дыхание, сердиебиение и другие жизненные процессы замедленны настолько, что могут быть обнаружены только с помощью специальной аппаратуры.

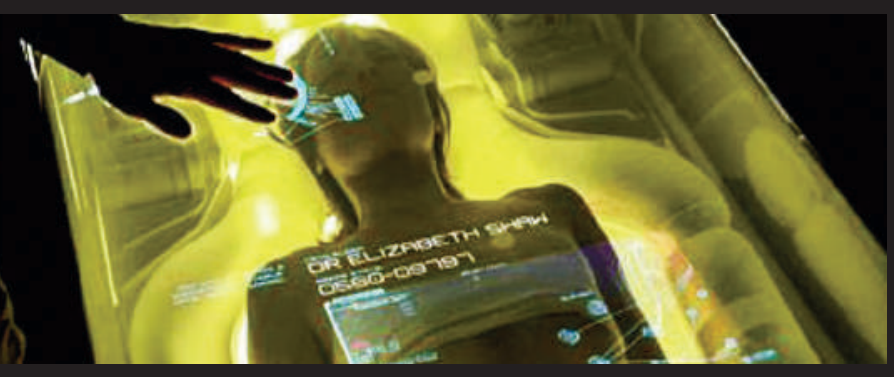

Предельная степень обратимого обезвоживания разных организмов

\begin{tabular}{l|c}
\hline Объект & обезвоживание, \% \\
\hline Коловратки, тихоходки, нематоды & 100 \\
\hline Кольчатые черви & $\mathbf{7 5}$ \\
\hline Насекомые & $12-26$ \\
\hline Амфибии & $33-47$ \\
\hline Пресмыкающиеся & 14 \\
\hline Мышь & 34 \\
\hline Человек & 10 \\
\hline
\end{tabular}




\section{2. ТЕХНОЛОГИЧЕСКАЯ БАЗА РЕАЛИЗАЦИИ КОСМИЧЕСКИХ LIFЕ-ТЕХНОЛОГИЙ}

\section{1. АНАЛОГИ БИОЛОГИЧЕСКИХ сTPУКТУР}

Реализуя бионические принципы при создании космической техники будущего, можно идти двумя путями:

- копирования биологических структур;

- создания биоморфных систем из материалов, более устойчивых к факторам космического пространства и иных планет, чем органические компоненты живых объектов, на соответствующей элементной базе.

Доступная в настоящее время элементная компонентная база уже позволяет достичь технологической плотности, необходимой для создания, к примеру, искусственного (электронного) мозга (puc. 9) [14].
Технологической основой создания искусственного мозга может послужить нейроморфный чип (рис. 10).

Основной компонентой нейроморфного чипа является синапс или система передачи возбуждения от нейрона к нейрону. В США и КНР ведется разработка трехмерного электронного синапса, потребляющего ультрамалые количества электроэнергии [19]. Основа разработки - материалы с переключаемым сопротивлением на основе оксида гафния.

\section{2. СОЗДАНИЕ ИСКУССТВЕННЫХ}

БИОЛОГИЧЕСКИХ СТРУКТУР

HА HOBЫХХ ПРИНЦИПАХ

Великий физик, лауреат Нобелевской премии Л.Д. Ландау утверждал: «Метод важнее открытия, ибо правильный метод исследования приведет к новым еще более ценным открытиям..." То есть в идеале мы должны стремиться овладеть "методом" природы, позволяющим творить новые материальныеживые/квазиживые объекты. В этой связи гораздо более перспективен путь ориентации на "природоподобные» технологии без прямого их копирования: более продуктивен перенос общих принципов функционирования живых объектов на существующую (альтернативную) компонентную базу. К примеру, нейроморфный чип на существующей полупроводниковой элементной базе будет работать на порядки быстрее биологического аналога [14, 15]. Воздушный винт (самолетный) в природе также не встречается, а полноценный машущий полет по образцу полета птиц до сих пор не реализован и т.д.

\section{РИС. 9. ЭЛЕМЕНТЫ БИОЛОГИЧЕСКОГО МОЗГА И ИХ ИСКУССТВЕННЫЕ АНАЛОГИ}

$\sim 10^{10}$ синапсов $/$ см $^{2}$
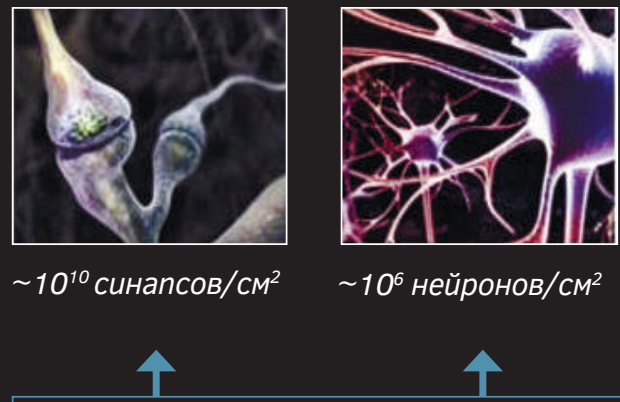

Нейроны

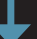

ТОЧКИ ПЕРЕСЕЧЕНИЯ

(p-n переходы)

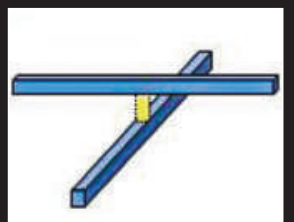

10 ${ }^{10}$ пересечений $\mathrm{CM}^{2}$ с шагом 10 нм

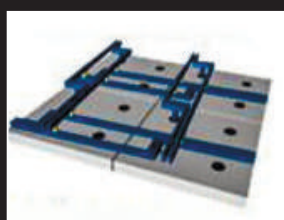
500 транзисторов $\sim 10^{6}$ нейронов/ см² $^{2}$

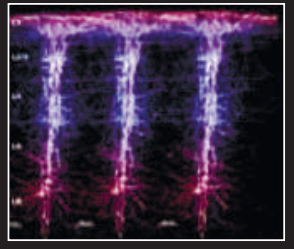

104 нейронов/ колонка неокортекса

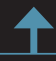

Микроструктуры

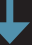
КРИСТАЛЫ МИКРОСХЕМ

$10^{8}$ транзисторов $/ \mathrm{CM}^{2}-$ на нейрон

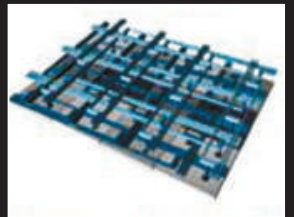

Многослойные кортикальные структуры

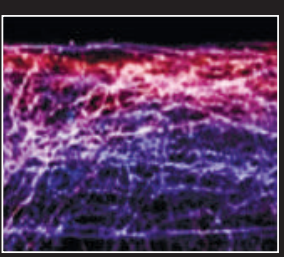

Межэлементные связи

ВЫСОКОСКОРОСТНАЯ $10^{6}$ нейронов/ $\mathrm{CM}^{2}$ $\sim 5 \cdot 10^{8}$ аксонов (нейтритов)
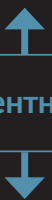
ШИНА

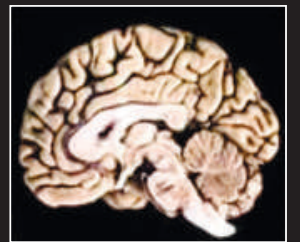

Биологический мозе

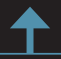

Мозг

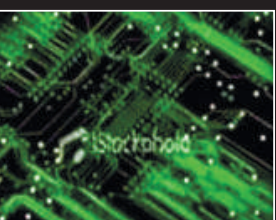

Несколько Гбит/с

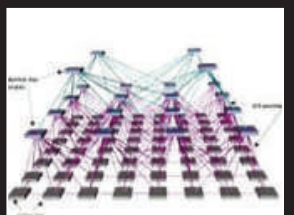

Электронный мозе 


\section{РИС. 10. НЕЙРОМОРФНЫЙ ЧИП - ТЕХНОЛОГИЧЕСКАЯ ОСНОВА ПОСТРОЕНИЯ ИСКУССТВЕННОГО (ЭЛЕКТРОННОГО) МОЗГА [19]}

(a)

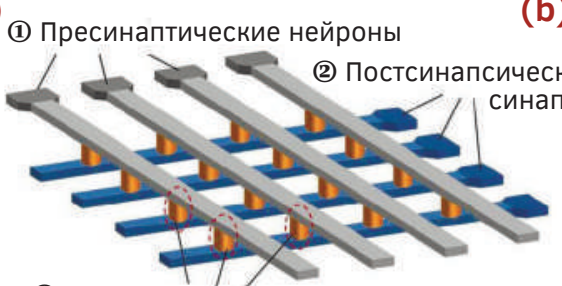

(3) Резистивные переключатели

(c) синапсов

Опорный электрод

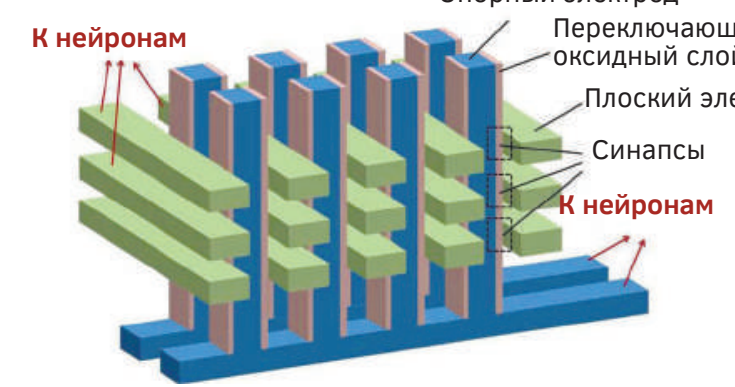

(e)

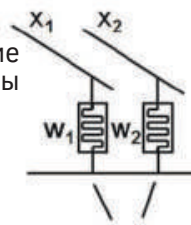

(3) Синапсы
(2) Нейрон

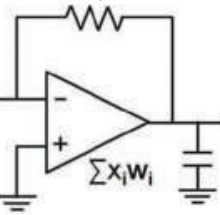

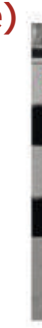

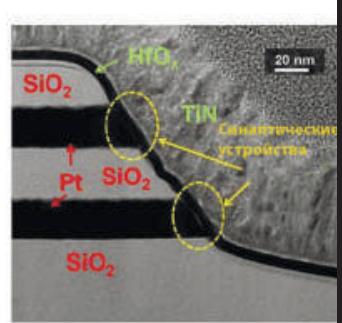

(d) Пресинаптический нейрон (2) нейрон (2)

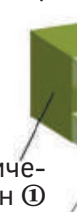

Пресинаптический нейрон (1)

От пресинаптических нейронов

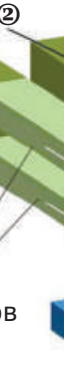

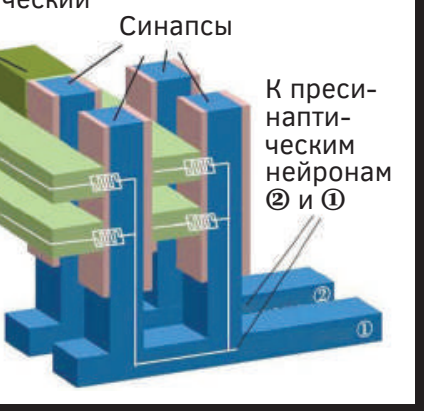

а) Обычный 2D-массив для электрической нейросети, где каждый синапс находится на пересечении проводящих линий пренейрона и постнейрона. b) Электрическая схема концепта с синапсами на основе устройства с переключаемым сопротивлением (resistive switching device).

c) Максимально компактная схема расположения синапсов (high-density application).

d) Схема расположения синапсов для вычислений с максимальной точностью (high-accuracy computation).

e) TEM-изображение noneречного среза электрического cuнаnca.

\section{РИС. 1l. АЛЬТЕРНАТИВНАЯ БИОХИМИЧЕСКАЯ ОСНОВА ЖИВЫХ ОБЪЕКТОВ}

\begin{tabular}{|c|c|c|}
\hline $\begin{array}{l}\text { Элемент (соеди- } \\
\text { нение) органиче- } \\
\text { ской жизни }\end{array}$ & $\begin{array}{l}\text { Альтернативный } \\
\text { элемент (соедине- } \\
\text { ние) неорганиче- } \\
\text { ской жизни }\end{array}$ & $\begin{array}{l}\text { Возможные свойства альтернативных } \\
\text { биохимических соединений }\end{array}$ \\
\hline Углерод+Водород & Азот+Фосфор & $\begin{array}{l}\text { В комплексе с азотом возможно образование более сложных ковалент- } \\
\text { ных связей, что делает возможным возникновение большого разнообразия } \\
\text { молекул, включая кольцевые структуры. Некоторые этапы цикла на основе } \\
\text { фосфора и азота являются энергодефицитными. }\end{array}$ \\
\hline \multirow[t]{3}{*}{ Вода } & Аммиак & $\begin{array}{l}\text { При давлении в } 1 \text { атм. находится в жидком состоянии при температурах } \\
\text { от -78 до -33 C. По ряду свойств напоминает воду, но при замерзании } \\
\text { твердый аммиак не всплывает вверх, а тонет (в отличие от водного льда). }\end{array}$ \\
\hline & Фтороводород & $\begin{array}{l}\text { Способен к образованию межммолекулярных водородных связей. Высокая реак- } \\
\text { ционная способность, в частности, с диоксидом кремния и алюмосиликатами. }\end{array}$ \\
\hline & Цианистый водород & $\begin{array}{l}\text { Соединение термодинамически неустойчиво. Довольно быстро осмоляется, } \\
\text { особенно в присутствии катализаторов (кислот, оснований, глины и др.). } \\
\text { Иногда разложение протекает со взрывом. }\end{array}$ \\
\hline
\end{tabular}


В последние годы выяснилось, что аналоги биомакромолекул могут быть построены не только на основе углерод-водородных полимеров, фосфора, воды и кислорода (рис. 11). Например, углерод-водородные соединения (алканы) могут быть заменены на кремний-водородные (силаны). Соединения кремния будут стабильнее углеродных молекул в среде серной кислоты, которая имеет некоторые преимущества перед водой благодаря увеличенному в несколько раз интервалу существования в жидкой форме и т. д. [16].

Таким образом, открываются перспективы создания исследовательских и промышленных биороботов, максимально адаптированных для работы в агрессивной среде планет Солнечной системы и их спутников.
Наконец получены первые результаты создания искусственной жизни - как физически, так и в форме компьютерных моделей (в качестве направления работ по искусственному интеллекту, рис. 12) [17].

В 2010 году американскому генетику Крейгу Вентеру впервые удалось „пересадить“ синтезированную ДНК из одной бактерии Mусоplasma mycoides в другую бактерию того же рода Mycoplasma capricolum. После пересадки дНК Mycoplasma capricolum благополучно размножалась, приобретая характеристики бактерии донора ДНК. Бактерия получила имя Mycoplasma laboratorium или Синтия (то есть синтетическая) и использовалась для ликвидации последствий разлива нефти в Мексиканском заливе.
Однако затем синтетическая бактерия мутировала, приобрела способность существовать на любом белковом субстрате и превратилась в одну из самых страшных угроз здоровью и жизни населения побережья Мексиканского залива США [18].

Если попытаться заглянуть в далекое будущее, можно предположить, что со временем появятся такие результаты конвергенции биологических и технических систем, как бионические („живые“) космические корабли. Идея биокорабля достаточно популярна в научно-фантастических произведениях и в компьютерных играх (рис. 13).

\section{ЗАКЛЮЧЕНИЕ}

Таким образом, могут быть сделаны следующие выводы:

1. В ближайшей перспективе целесообразно исследовать возможности реализации в космической технике принципов построения и функционирования биологических систем на существующей компонентной базе с целью создания:

- суперадаптивных изделий космической техники, обладающих, в том числе способностью к регенерации силовых конструкций, оболочек, элементов, агрегатов и систем;

- микроминиатюрных датчиков систем управления летательных аппаратов с высокими характеристиками точности, надежности и информативности, имитирующих принципы работы биологических навигационных датчиков;

- интеллектуальных автономных систем управления и поддержки принятия решений в нестандартных ситуациях, имитирующих работу головного мозга и нервной системы человека и т. д.

2. На более отдаленную перспективу может быть поставлена задача исследования возможностей создания изделий космической техники, отдельных приборов, агрегатов и элементной базы на основе неорганических (синтетических) живых структур, устойчивых к экстремальным внешним воздействиям, обладающих повышенной жизнеспособностью, включая способность к регенерации, а также возможностью репликации. 


\section{РИС. 12. СОЗДАНИЕ ИСКУССТВЕННЫХ ЖИВЫХ ОБЪЕКТОВ}

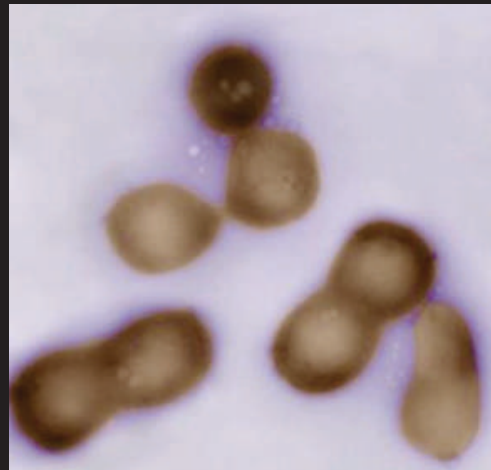

Синтезированная Мусорlasma mycoides JCVI 1.0 под электронным микроскопом

Крейгу Вентеру (Университет uтата Нью-Йорк в Буффьало, США) в 2010 году удалось «nересадить» синтезированную ДНК из одной бактерии Mусорlasma mycoides в другую бактерию mого же рода Mycoplasma capricolum. После пересадки ДНК Mycoplasma capricolum благополучно размножалась, приобретя характеристики бактерии донора ДНК. Бактерия получила имя Синтия (JCVI-syn 1.0). Использовалась для ликвидации последствий разлива нефти в Мексиканском заливе. Однако затем мутировала и стала способна существовать на любом белковом субстрате.

\section{Проекты создания и исследования цифровой синтетической жизни}

\begin{tabular}{|c|c|c|}
\hline Проект & Авторы & Описание \\
\hline Ascape & $\begin{array}{l}\text { Центр исследова- } \\
\text { ния социальных } \\
\text { и экономических } \\
\text { явлений, институт } \\
\text { Брукинса, США }\end{array}$ & $\begin{array}{l}\text { Java-среда моделирования и анализа поведе- } \\
\text { ния групп автономных агентов. Обновлялась в } \\
2000 \text { году. }\end{array}$ \\
\hline DDLab & $\begin{array}{l}\text { Андрей Вьюнш, } \\
\text { компания Discrete } \\
\text { Dynamics Lab }\end{array}$ & $\begin{array}{l}\text { Система создания клеточных автоматов с } \\
\text { многомерной логикой, использующая техноло- } \\
\text { гию случайных логических сетей. Обновлена в } \\
\text { декабре } 2004 \text { года. }\end{array}$ \\
\hline Framsticks & $\begin{array}{l}\text { Группа польских } \\
\text { энтузиастов }\end{array}$ & $\begin{array}{l}\text { Мощная система трехмерного моделирова- } \\
\text { ния, имитирующая эволюцию особей в мире, } \\
\text { напоминающем земной. При этом корректно } \\
\text { реализованы понятия генотипа, физического } \\
\text { организма, мозга и неовной системы (нейрон- } \\
\text { ные модели), цепочки восприятия (среда - ре- } \\
\text { цепторы - мозг - эффекторы - среда) и общей } \\
\text { экосистемы. Обновлена в августе } 2004 \text { года. }\end{array}$ \\
\hline $\begin{array}{l}\text { Ant Farm, } \\
\text { Ant World }\end{array}$ & $\begin{array}{l}\text { Роберто Матура- } \\
\text { на, Испания; Бен } \\
\text { Бланделл, Вели- } \\
\text { кобритания }\end{array}$ & $\begin{array}{l}\text { Симуляторы поведения муравьев Ant Farm - } \\
\text { одни из лучших в этом классе по наглядности. } \\
\text { Его коллега Ant World более сложный и менее } \\
\text { красивый, но содержит немало надстроечных } \\
\text { параметров и средств анализа. }\end{array}$ \\
\hline Evolutionz & $\begin{array}{l}\text { Дмитрий Мари- } \\
\text { канис, Филипп } \\
\text { Канзл, Канада }\end{array}$ & $\begin{array}{l}\text { Трехмерная модель среды, в которой искус- } \\
\text { ственные насекомые, управляемые ней- } \\
\text { ронными сетями, конкурируют за пищевые } \\
\text { ресурсы. Позволяет проводить эксперименты } \\
\text { по созданию стабильной экосистемы путем } \\
\text { манипулирования различными параметрами. } \\
\text { За счет сложности среды каждый сеанс ра- } \\
\text { боты формирует уникальный мир и позволяет } \\
\text { изучать оригинальные стратегии выживания. }\end{array}$ \\
\hline
\end{tabular}

\section{РИС. 13. БИОНИЧЕСКИЕ КОСМИЧЕСКИЕ КОРАБЛИ (ИЗ ФАНТАСТИЧЕСКИХ ПРОИЗВЕДЕНИЙ)}

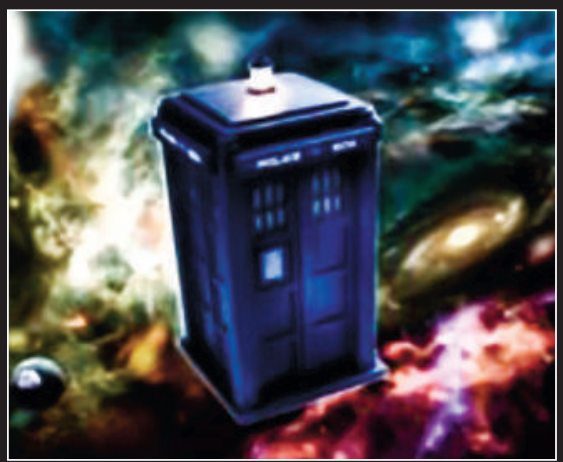

ТАРДИС («Доктор Кто») - живой корабль для перемещения в пространстве и времени. Его не строят, а вырацивают.

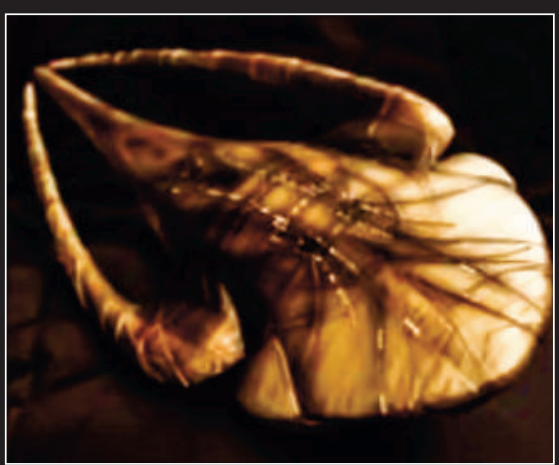

Мойя (сериал Faescape) - разумный транспортный корабль из расы левиафанов.
Биокорабль, живой корабль - тuп космического корабля в научной фбантастике, часто описывается как звездолет. Биокорабли отличаются от большинства космических аппаратов тем, что частично или полностью состоят из биологических материалов. Биокораблям приписывают способность регенерировать или залечивать повреждения. Некоторые биокорабли обладают интеллектом или даже разумны, некоторые являются живыми организмами. Как и большинство органических борм жизни, многие биокорабли имеют большое количество мертвых материалов, таких как кости или хитин у животных, или даже искусственные компоненты. (Buкuпедия) 


\section{Литература}

1. Ахметов Р.Н., Макаров В.П., Соллогуб А.В. Байпасность как атрибут живучести автоматических космических аппаратов в аномальных полетных ситуациях // Вестник Самарского государственного аэрокосмического университета. Самара, 2015. T. 14. № 4. С. 17-37.

2. Ахметов Р.Н., Макаров В.П., Соллогу6 А.В. Особенности обеспечения целевой эффективности космических аппаратов зондирования Земли на основе методов рефакторинга и обратной инженерии // Онтология проектирования. 2012. № 4. С. 7-17.

3. Бегляров В.В., Береза А.Н., Ляшов М.В. Аналитический обзор реконфигурируемых гибридных эволюционных аппаратных систем // Известия Южного федерального университета. Технические науки. Таганрог, 2009. Выпуск № 12. Том 101. С. 27-32.

4. Савкин Л.В. Регенеративные электронные системы в космических системах и комплексах // Вестник кибернетики. 2015. № 2 (18). C. 3-32.

5. Andersson, J.-O., Helander, T., Höglund, L., Shi, P. \& Sundman, B. Thermo-Calc \& DICTRA, computational tools for materials science. Calphad, 2002, vol. 26, no. 2 , pp. 273-312.

6. Чумаков Д.М. Перспективы использования аддитивных технологий при создании авиационной и ракетно-космической техники // Труды МАИ. 2014. Выпуск 78. URL: http://www.mai.ru/science/trudy/(Дата обращения: 13.01.2017)

7. Солнечные панели, работающие на принципе фотосинтеза [Электронный ресурс] // Проект Заряд, 2018. URL: http://zaryad. com/2012/04/09/solnechnyie-panelirabotayushhie-na-printsipe-fotosinteza/(Дата обращения: 13.01.2018).

8. Высоцкий В.И., Корнилова А.А. Трансмутация радионуклидов в биологических системах - реанимация фантазии алхимии или лабораторная реальность? // Радиоэлектроника. Наносистемы. Информационные технологии. 2014. Выпуск 1. Том 6. C. 99-109.

9. Анохин К.В. Когнитом: сетевое расширение теории функциональных систем [Электронный ресурс] // Современные проблемы системной регуляции физиологических функций. Материалы конференции. М.: ФГБНУ «НИИНФ им. П.К. Анохина», 2015. C. 3-5. URL: http://znanium.com/catalog. php?bookinfo $=529073$ (Дата обращения: 13.01.2018)

10. Селезнев В.П., Селезнева Н. В. Навигационная бионика. М.: Машиностроение, 1987. $256 \mathrm{c}$.

11. Allen, J. Me and the biospheres: a memoir by the inventor of Bioshpere-2. Synergetic Press, Santa Fe, 2008. 308 p.

12. Тернистый путь замкнутых биологических систем жизнеобеспечения
[Электронный ресурс] // AfterShock, 2018. URL: https://aftershock. news/?q=node/299518\&full (Дата обращения: 01.10.2018).

13. Torpor Inducing Transfer Habitat For Human Stasis To Mars. Grant Number NNX13AP82G. Prepared by John E. Bradford, Douglas Talk. 11 May 2014. Version 1.0. 73 p. 14. Have you heard of SyNAPSE? [Электронный ресурc]//21st Century Tech Blog, 2018. URL: https://www.21stcentech.com/heardsynapse/(Дата обращения: 30.09.2018).

15. Bin Gao, Yingjie Bi and all. Ultra-LowEnergy Three-Dimensional Oxide-Based Electronic Synapses for Implementation of Robust High-Accuracy Neuromorphic Computation Systems//ACS Nano, 2014, no. 8 (7), pp. 6998-7004.

16. Синтетическая биология - применение и угрозы [Электронный ресурс] // Наука за рубежом. 2014. № 36. URL: http://www. issras.ru/global_science_review/(Дата обращения: 13.01.2018).

17. Топунов А.Ф., Шумаев К.Б. Альтернативная биохимия и распространенность жизни // Бюллетень специальной астрофизической обсерватории РАН, 2007. Вып. 60-61. С. 106-110.

18. Алехин М.Д., Клабуков И.Д., Мусиенко С. В. Нанобиотехнологии в перспективных космических экспериментах. Конференция серии «Будущее индустрии»: Living AeroSpace 2012/Москва, 2012. 30 c. 


\section{References}

1. Akhmetov R.N., Makarov V.P., Sollogub A.V. Baypasnost' kak atribut zhivuchesti avtomaticheskikh kosmicheskikh apparatov $v$ anomal'nykh poletnykh situatsiyakh // Vestnik Samarskogo gosudarstvennogo aerokosmicheskogo universiteta, 2015, vol.14, no. 4, pp. 17-37.

\section{Akhmetov R.N., Makarov V.P., Sol-} logub A.V. Osobennosti obespecheniya tselevoy effektivnosti kosmicheskikh apparatov zondirovaniya Zemli na osnove metodov refaktoringa i obratnoy inzhenerii. Ontologiya proektirovaniya, 2012, no. 4, pp. 7-17.

\section{Beglyarov V.V., Bereza A.N., Lyash-} ov M.V. Analiticheskiy obzor rekonfiguriruemykh gibridnykh evolyutsionnykh apparatnykh sistem. Izvestiya Yuzhnogo federal'nogo universiteta. Tekhnicheskie nauki. Taganrog, 2009 , iss. 12 , vol. 101, pp. 27-32.

4. Savkin L. V. Regenerativnye elektronnye sistemy v kosmicheskikh sistemakh i kompleksakh. Vestnik kibernetiki, 2015, no. 2 (18), pp. 3-32.

\section{Andersson, J.-O., Helander, T., Höglund,} L., Shi, P. \& Sundman, B. Thermo-Calc \& DICTRA, computational tools for materials science. Calphad, 2002, vol. 26, no.2, pp. 273-312.

6. Chumakov D.M. Perspektivy ispol'zovaniya additivnykh tekhnologiy pri sozdanii aviatsionnoy i raketno-kosmicheskoy tekhniki.
Trudy MAI, 2014, iss. 78. Available at: http://www.mai.ru/science/trudy/(Retrieval date: 13.01.2017)

7. Solnechnye paneli, rabotayushchie na printsipe fotosinteza. Available at: http://zaryad.com/2012/04/09/solnechnyie-paneli-rabotayushhie-na-printsipe-fotosinteza/(Retrieval date: 13.01.2018).

8. Vysotskiy V.I., Kornilova A.A. Transmutatsiya radionuklidov $v$ biologicheskikh sistemakh - reanimatsiya fantazii alkhimii ili laboratornaya real'nost'? Radioelektronika. Nanosistemy. Informatsionnye tekhnologii. 2014, iss. 1, vol. 6, pp. 99-109.

9. Anokhin K.V. Kognitom: setevoe rasshirenie teorii funktsional'nykh system. Sovremennye problemy sistemnoy regulyatsii fiziologicheskikh funktsiy. Moscow: FGBNU «NIINF im. P.K. Anokhina», 2015, pp. 3-5. Available at: http://znanium.com/catalog. php? bookinfo $=529073 /$ (Retrieval date: 13.01.2018).

10. Seleznev V.P., Selezneva N. V. Navigatsionnaya bionika. Moscow: Mashinostroyeniye, 1987. $256 \mathrm{p}$.

11. Allen, J. Me and the biospheres: a memoir by the inventor of Bioshpere-2. Synergetic Press, Santa Fe, 2008. 308 p.

12. Ternistyy put' zamknutykh biologicheskikh sistem zhizneobespecheniya. Available at: https://aftershock. news/?q=node/299518\&full (Retrieval date: 01.10.2018).
13. Torpor Inducing Transfer Habitat For Human Stasis To Mars. Grant Number NNX13AP82G. Prepared by John E. Bradford, Douglas Talk. 11 May 2014. Version 1.0. 73 p.

14. Have you heard of SyNAPSE? Available at: https://www.21stcentech. com/heard-synapse/(Retrieval date: 30.09.2018).

15. Bin Gao, Yingjie Bi and all. Ultra-Low-Energy Three-Dimensional Oxide-Based Electronic Synapses for Implementation of Robust High-Accuracy Neuromorphic Computation Systems//ACS Nano, 2014, no. 8 (7), pp. 6998-7004.

16. Sinteticheskaya biologiya - primenenie i ugrozy. Nauka za rubezhom, 2014, no. 36. Available at: http://www.issras.ru/global_science_review/(Retrieval date: 13.01.2018)

17. Topunov A. F., Shumayev K. B. Al'ternativnaya biokhimiya i rasprostranennost' zhizni. Byulleten' spetsial'noy astrofizicheskoy observatorii RAN, 2007, iss. 60-61, pp. 106-110.

18. Alekhin M.D., Klabukov I. D., Musienko S.V. Nanobiotekhnologii v perspektivnykh kosmicheskikh eksperimentakh. Budushchee industrii, Living AeroSpace 2012/Moscow, 2012, $30 \mathrm{p}$.
() Клюшников В. Ю., 2018

\section{История статьи:}

Поступила в редакцию: 03.10.2018

Принята к публикации: 29.10.2018

Модератор: Гесс Л.А.

Конфликт интересов: отсутствует

Для цитирования:

Клюшников В. Ю. LIFE-технологии - будущее космической техники // Воздушно-космическая сфера. 2018. №4(97). С. 28-43. 